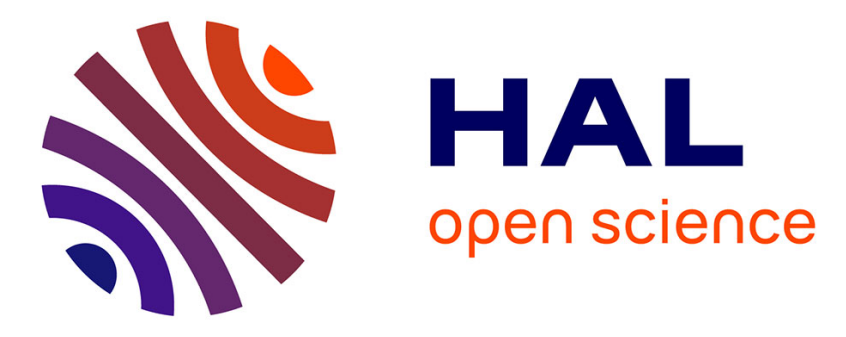

\title{
DUX 4 and DUX4 downstream target genes are expressed in fetal FSHD muscles
}

\author{
M Ferreboeuf, V. Mariot, B. Bessières, A Vasiljevic, Tania Attié-Bitach, S \\ Collardeau, Stéphane Roche, Frédérique Magdinier, Jérôme Robin-Ducellier, \\ P Rameau, et al.
}

\section{To cite this version:}

M Ferreboeuf, V. Mariot, B. Bessières, A Vasiljevic, Tania Attié-Bitach, et al.. DUX 4 and DUX4 downstream target genes are expressed in fetal FSHD muscles. 18th International Congress of The World Muscle Society, Oct 2013, Pacific Grove, CA, United States. pp.823, 10.1016/j.nmd.2013.06.640 . hal-01907613

\section{HAL Id: hal-01907613 https://hal.science/hal-01907613}

Submitted on 9 Nov 2018

HAL is a multi-disciplinary open access archive for the deposit and dissemination of scientific research documents, whether they are published or not. The documents may come from teaching and research institutions in France or abroad, or from public or private research centers.
L'archive ouverte pluridisciplinaire HAL, est destinée au dépôt et à la diffusion de documents scientifiques de niveau recherche, publiés ou non, émanant des établissements d'enseignement et de recherche français ou étrangers, des laboratoires publics ou privés. 
We show that DUX4-FL is not expressed in control myotubes whereas it is expressed FSHD myotubes. Interestingly, DUX4-FL expression level is much lower in trapezius than in quadriceps myotubes which is confirmed by the level of expression of DUX4 downstream genes: We observed that TRIM43 and MBD3L2 are already overexpressed in FSHD fetal quadriceps biopsies, at similar levels at those observed in adult FSHD quadriceps biopsies.

These results indicate that molecular markers of the disease are already expressed during fetal life, raising the question as to the role of DUX4 in the onset and progression of FSHD.

P.16.3

DUX 4 and DUX4 downstream target genes are expressed in fetal FSHD muscles

M. Ferreboeuf ${ }^{1}$, V. Mariot $^{1}$, B. Bessières ${ }^{2}$, A. Vasiljevic ${ }^{3}$, T. AttiéBitach $^{2}$, S. Collardeau ${ }^{3}$, S. Roche ${ }^{4}$, F. Magdinier ${ }^{4}$, J. Robin-Ducellier ${ }^{5}$, P. Rameau ${ }^{6}$, S. Whalen ${ }^{7}$, S. Sacconi ${ }^{8}$, V. Mouly ${ }^{1}$, G. Butler-Browne ${ }^{1}$, J. Dumonceaux ${ }^{1}$

${ }^{1}$ Université Pierre et Marie Curie, Paris, France; ${ }^{2}$ Université Paris Descartes, Paris, France; ${ }^{3}$ CHU-Lyon, Bron, France; ${ }^{4}$ Faculté de Médecine de la Timone, Marseille, France; ${ }^{5}$ UT Southwestern Medical Center, Dallas, United States; ${ }^{6}$ Institut Gustave Roussy, Villejuif, France; ${ }^{7}$ Groupe hospitalier Pitié-Salpétrière, Paris, France; ${ }^{8}$ Nice University Hospital, Nice, France

The facio scapulo humeral dystrophy (FSHD) is the third most prevalent muscular dystrophy. The common clinical signs usually appear during the second decade of life but when the first molecular dysregulations occur is still unknown. Our aim was to determine whether molecular dysregulations can be identified during FSHD fetal muscle development. We compared 2 muscle biopsies coming from one FSHD fetus and the cells derived from these biopsies with biopsies and cells coming from control fetuses. We mainly focus on DUX4 isoform expression since the expression of DUX4 has been confirmed in both FSHD cells and biopsies by several laboratories.

We measured by qRT-PCR DUX4 isoforms expression in fetal FSDH myotubes treated or not with a shRNA directed against DUX4 mRNA. We also analyzed DUX4 downstream genes expression in myotubes and fetal or adult FSDH and control quadriceps biopsies. 